\title{
Výskyt sovy dlhochvostej (Strix uralensis) v lesoch Národného parku Malá Fatra (severozápadné Slovensko)
}

\author{
Occurrence of the Ural owl (Strix uralensis) in forests of the Malá \\ Fatra National Park (NW Slovakia)
}

\section{Tomáš FLaJS}

Štátna ochrana prírody SR, Správa Národného parku Malá Fatra, Hrnčiarska ulica 197, 01303 Varín, Slovakia; e-mail: tomas.flajs@sopsr.sk

\begin{abstract}
In total, presence of Ural owl (Strix uralensis) was monitored on 245 sites in the area of the Malá Fatra National Park, NW Slovakia, in 2013-2016. The sites were selected systematically over the entire protected area. Acoustic monitoring using automatic digital voice recorders and direct observations were repeatedly performed on these sites. Altogether, 18 breeding territories of Ural owls were found there. The species was found in old mixed forests (over 130 years) there. These forest stands are located mainly in nature reserves or in areas with limited forest management. It is likely that the lack of trees or snags suitable for nesting may limit species density in managed forests.
\end{abstract}

Key words: owl abundance, nature reserves, forest management, habitat fragmentation

\section{Úvod}

Sova dlhochvostá (Strix uralensis) je obyvatel'om lesných biotopov východného a stredného Slovenska (Krištín et al. 2007). Černecký et al. (2014) uvádzajú odhad hniezdnej populácie pre Slovensko v počte 1400 - 2500 párov, za roky 2000 - 2012 uvádzajú pre druh rastúci populačný trend, podobne rastúci populačný trend uvádzajú aj pri dlhodobom trende za roky 1980 - 2012. Druh hniezdi najmä v listnatých, zmiešaných a zriedkavejšie aj v čistých ihličnatých lesoch (Karaska et al. 1997, Danko et al. 2002), pričom sa z lesov v stredných a vyšších polôh presúva pre vyhl'adávanie nových hniezdnych príležitostí príp. pre l'ahšiu možnost' lovu koristi v zimnom období aj k nížinám (Lengyel 2004, Balla 2010). Typicky hniezdi v niekol'ko metrov vysokých polozhnitých pahýl'och hrubších kmeňov stromov. $Z$ tohto dôvodu vyhl'adáva najmä staršie lesné porasty pralesovitého charakteru, lesné rezervácie či ochranné porasty (Bylicka et al. 2010). Obýva skôr redšie porasty bez výraznejšieho podielu podrastu umožňujúce l'ahší lov koristi. Obvykle obsadzuje väčšie lesné komplexy, často závery dolín, v podhrebeňových častiach (Karaska et al. 2014). Ako hniezdič bol druh výnimočne zistený aj v čistých smrečinách (Karaska et al. 1997). Vo vysokých pohoriach vystupuje ako hniezdič až do výšky nad $1000 \mathrm{~m}$ n. m. (Oravská Magura, Západné Tatry, Karaska et al. 1997, Pol'ana, Krištín 1991, Urban \& Malatinec 1994). U tohto druhu je v rámci územia Slovenska zaznamenaný výrazný postup západným smerom približne od 70. rokov minulého storočia (Danko et al. 2002, Krištín et al. 2007). Výskyty boli potvrdené aj v oblasti Moravsko-sliezskych Beskýd (Vermouzek et al. 2004). Z oblasti južného Pol'ska o podobnom vývoji populácie píše aj Chylarecki et al. (2009), 
z územia Nemecka Schäffer (1993). V niektorých oblastiach sa pristúpilo aj ku reintrodukcii druhu, napr. na Šumave (Kloubec 1997, Bufka \& Kloubec 1999) a v Rakúsku (Engleder 2003). Sova dlhochvostá sa na rozdiel od sovy lesnej vyhýba l'udským sídlam, pribúdajú však informácie o zimovaní prevažne mladých vtákov v otvorenej pol'nohospodárskej krajine a potravnej špecializácii druhu v urbánnom prostredí (Dravecký \& Obuch 2009, Baláž et al. 2018).

$\mathrm{Z}$ územia Malej Fatry je prvý známy údaj sovy dlhochvostej z roku 1992 (Majda M. in Danko 1994), ked' sa tam predpokladalo hniezdenie na základe nálezu letky a kormidlového pera na obsadenom hniezde orla skalného (Aquila chrysaetos). Neskorší známy údaj jedného jedinca v Lysici v k. ú. Párnica je z 2. 12. 1996 (Karaska et al. 1997). Prvé dokázané hniezdenie v Krivánskej Fatre sa podarilo až v r. 2004 v NPR Šrámková, kde bol pozorovaný tokajúci pár 20. 4. 2004 počas večerného a nočného sčítania vtákov. Samec si typickým teritoriálnym húkaním obhajoval hniezdne teritórium v nadmorskej výške 825 - 900 m. Pri priblížení $\mathrm{k}$ suchému stojacemu kmeňu jedle bielej agresívne klepal zobákom a nalietaval na pozorovatel'a. Pravdepodobne šlo o hniezdny kmeň, ale hniezdo nebolo kontrolované z dôvodu vysokej rizikovosti pádu tlejúceho kmeňa (Korňan 2008). Z literatúry z tohto územia nie sú známe d'alšie pozorovania (od roku 1992 po súčasnost'). Pre CHVÚ Malá Fatra (Krivánska aj Lúčanská čast') bola v roku 2012 definovaná populácia sovy dlhochvostej ako stabilná na úrovni 25 - 30 hniezdnych párov, v roku 2003 bola početnost' odhadnutá na 30 hniezdnych párov. Celkový stav druhu je hodnotený ako priemerný, teda priaznivý stav, stav populácie a stav biotopov sa nachádza tiež v priemernom, priaznivom stave (ŠOP 2015).

Ciel'om práce bolo zistit' stav rozšírenia a početnosti druhu na území Národného parku (čast' Krivánska Malá Fatra), na základe získaných opakovaných nočných nahrávok z územia v kombinácii s vlastným terénnym prieskumom v mesiacoch február až jún počas rokov 2013 až 2016. V práci bol riešený aj výber stanovíšt' sovy v území, lesné porasty z hl'adiska ochrany, veku, druhového zloženia, zakmenenia, expozície a hniezdnej hustoty druhu v skúmanej oblasti.

\section{Materiál a metodika}

\section{Sledované územie}

Národný park Malá Fatra sa nachádza v SZ časti Slovenska. Medzi mestami Dolný Kubín, Martin a Žilina $\left(49^{\circ} 07^{\prime} 30-49^{\circ} 15^{\prime} 30^{\prime \prime}\right.$ zemepisnej šírky a $18^{\circ} 52^{\prime} 30^{\prime \prime}-19^{\circ} 13^{\prime} 00^{\prime \prime}$ zemepisnej dížky) s výmerou 22630 ha a zasahuje do niekol'kých horských celkov a podcelkov Fatransko-tatranskej oblasti a Stredných Beskýd. Krivánska Malá Fatra, ktorá je súčast’ou Národného parku, sa vzhl'adom na mimoriadne vysokú bio(-geo-eko)diverzitu považuje za jeden z najcennejších regiónov Západných Karpát (Janáčik 1971, Midriak \& Urbanová 1981, Šibík et al. 2015). Územie sa vyznačuje pôvodnými a relatívne dobre zachovalými ekosystémami i ked' územia s hospodárskymi lesmi nesú známky intenzívneho hospodárenia s často úplne nevhodnou premenou porastov. NP Malá Fatra má pokryvnost' lesa až 18833 ha čo predstavuje 83,2 \% územia, pričom hospodárske lesy tvoria $27,1 \%$ plochy chráneného územia, ochranné lesy $(66,1 \%)$ a lesy osobitného určenia $(0,5 \%)$. Približne $6,4 \%$ sa nachádza mimo les (Kalaš 2016).

\section{Zber dát}

Nahrávacie prístroje (diktafón Olympus DM650) boli inštalované za predpokladu priaznivých klimatických a akustických podmienok v štvorcovej sieti $(2 \times 2 \mathrm{~km}$, počet diktafónov sa pohyboval od 3 po 6 prihliadajúc na geomorfológiu územia) v celom mapovanom území. Spolu bolo vytvorených 245 nahrávacích bodov (219 v NP, 26 do $100 \mathrm{~m}$ od hranice NP). Získané nahrávky boli analyzované v programe Audacity (https://www.audacityteam.org/) a následne porovnávané pre stanovenie počtu ozývajúcich sa jedincov sov. Všetky zaznamenané druhy sov, početnost', charakteristika ich hlasov, opakovanost' a d'alšie špecifické informácie boli ku každej nahrávke zapisované, približná vzdia- 
lenost' (odhad do 50 m, 200 m, $500 \mathrm{~m}$ a viac) a poloha húkajúcich sov bola zaznačovaná na mape. Odhad vzdialenosti a smeru húkania jedincov bol porovnávaný s nahrávačmi na vedl'ajších bodoch. Výsledky boli porovnávané a vyhodnotené spolu s výsledkami z vlastného nočného terénneho prieskumu. Nahrávače boli na lokalitách umiestňované opakovane s určitým časovým odstupom. Vždy sa nahrávali dve po sebe idúce noci. Ďalšia expozícia prístrojov bola po 10 až 15 dňoch na rovnakých miestach. V prípade nevhodných akustických podmienok (vietor, zrážky, blízko vedúca cesta a železničná siet' v predhorí územia, vodný tok, blízkost' obce, veterne exponované hrebene, ustajnené hospodárske zvieratá, ruch okolo horskej chaty, nočná úprava lyžiarskych vlekov, aktuálne vykonávané lesohospodárske aktivity) sa nahrávanie a kontrola opakovala. Hniezdne teritóriá boli identifikované na základe opakovaných hlasových prejavov, ked’že sovy sa počas toku najčastejšie ozývajú v porastoch spravidla v blízkosti hniezda (Korpimäki 1988,
Strøm \& Sonerud 2001, Vrezec 2003, Vrezec \& Tome 2004, Karaska 2007, Ortego 2007, Pačenovský \& Shurulinkov 2008, Chylarecki et al. 2009, Brambilla 2010, Morosinotto et al. 2010, Shurulinkov et al. 2012). Počas nočného monitoringu na lokalitách nebolo pristupované ku hlasovému vábeniu jedincov, zistené údaje pochádzajú iba z ich prirodzených prejavov. Všetky potrebné informácie o vekovej a druhovej štruktúre boli získané z vol'ne dostupných podkladov Národného lesníckeho centra vo Zvolene (http://gis.nlcsk.org/lgis/).

\section{Výsledky}

Mapovaním akustickej aktivity sov v rokoch 2013 - 2016 sa zistilo rozmiestnenie 18 teritórií sovy dlhochvostej na území NP Malá Fatra (obr. 1).

Jednotlivé lokality sú pomenované podl'a miestnych najbližších názvov. Bližší opis lesných porastov s opakovaným výskytom druhu v NP Malá Fatra:

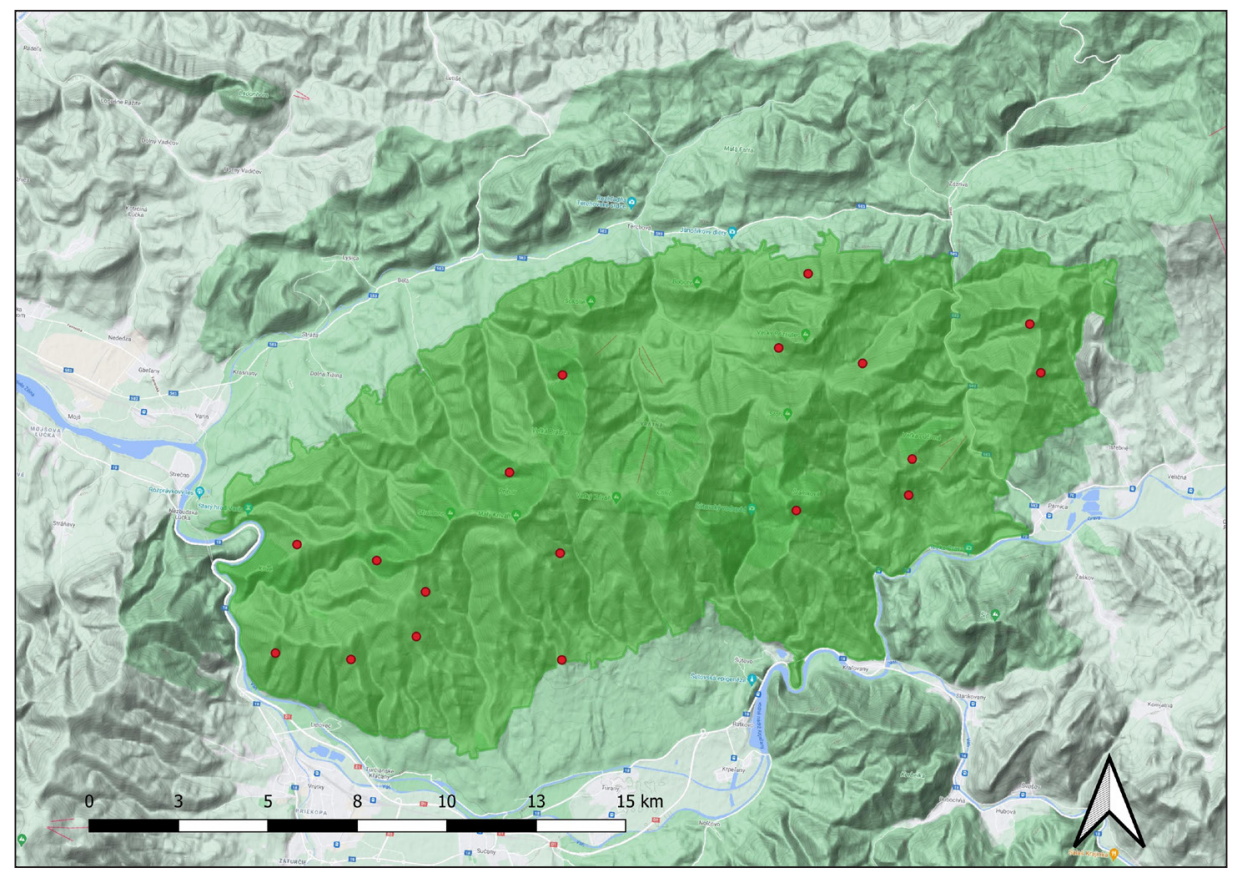

Obr. 1. Hniezdne teritóriá sovy dlhochvostej $(n=18)$ na území Národného parku (NP) Malá Fatra (červené body). Fig. 1. Breeding territories of the Ural owl $(n=18)$ in the Malá Fatra National Park (NP) (red dots). 
Kačov (k. ú. Párnica)

Pravidelné akustické pozorovania pochádzajú z porastov južne od Magurky, v oblasti Ivaškovej, Kykuly a Kykulky v nadmorskej výške $800-1000 \mathrm{~m}$ n. m. Ide o hospodársky bukový les (asi 165 ročný, J expozícia), výnimočne je tam smrek a jedl'a.

\section{Vel'ká Lučivná (k. ú. Párnica)} Porast (asi 190 ročný, 60 \% smrek, 40 \% buk) sa nachádza v NPR Vel'ká Lučivná prípadne vo vedl'ajšom lese ochranného typu. Pár sov bol opakovane akusticky registrovaný na viacerých lokalitách v úseku od Magurky po Strungový príslop vo výške $1000-1200 \mathrm{~m} \mathrm{n}$. m. V roku 2016 boli v širšom okolí lokality pozorované dve slabo lietajúce mlád'atá (Kalaš in verb.). Opakovane zaznamenaný pravidelný spoločný tok oboch jedincov.

Hrčova Kečka od Lysice (k. ú. Párnica)

Porasty s opakovanými akustickými prejavmi sa nachádzajú na južných svahoch Hrčovej Kečky (hospodársky les asi 140 ročný), $900-1100$ m n. m, alebo v masíve Lysice $(900-1100$ m n. m., súčast' NPR Sokolec, západná strana). Zmiešaný les má zastúpenie buka $30 \%$, jedle $30 \%$, smreka $40 \%$. Na lokalite bol v priebehu celého monitoringu zistený spoločný tok oboch jedincov sovy dlhochvostej.

\section{Zlatná pod Pekelníkom (k. ú. Tu-} rany)

Opakované hlasové prejavy pochádzali zo strmých svahov Mojského Grúňa (900 - 1000 m n. m. ochranný les) a Javoriny (1000 - 1200 $\mathrm{m} n$. m. ochranný les). Vek porastu je približne 160 rokov, zastúpenie buka $70 \%$ a smreka 30 $\%$, JV expozícia lesa. Na lokalite bol v priebehu celého monitoringu zistený spoločný tok oboch jedincov sovy dlhochvostej

\section{Belská dolina (k. ú. Belá)}

Predpokladaná hniezdna lokalita sa nachádza pod Holiami, v asi 135 r. bukovo jedl'ových porastoch (80: $20 \%$, Z exp.) NPR Prípor. Na lokalite bol v priebehu celého monitoringu zistený spoločný tok oboch jedincov sovy dlhochvostej (950 - 1200 m n. m.)

Istebnianska dolina (k. ú. Istebné) Na lokalite bol opakovane zaznamenaný spoločný tok sov a hlasové prejavy pochádzali z nadmorských výšok $900-1100$ m. Pri tejto lokalite bolo podozrenie na jeden pár s vedl'ajšou lokalitou Hrčova Kečka. No na základe opakovaných a záznamov aj fyzickej nočnej kontroly šlo o dva rozdielne páry. Vek porastu je približne 120 rokov (buk $90 \%$, smrek $5 \%$, jedl'a $5 \%$ ), ide o JV expozíciu porastov ochranného charakteru. Na lokalite sú záznamy tokajúcich sov počas celého monitoringu.

Nad Pekelnou dolinou (k. ú. Lipovec)

Opakované hlasové prejavy pochádzali najmä z porastov NPR Suchý $(900-1200 \mathrm{~m} \mathrm{n}$. m.). Vek porastu je 180 rokov (buk $60 \%$, jedla $10 \%$, smrek $20 \%$, $10 \%$ cenné listnáče na južne položených svahoch).

\section{Panošiná (k. ú. Lipovec)}

Opakované hlasy páru pochádzali z porastov vo výškach 750 - $900 \mathrm{~m} \mathrm{n}$. m. Približne 130 ročný porast predstavuje $95 \%$ buk a $5 \%$ hrab, ide o južnú expozíciu porastov ochranného typu.

NPR Šrámková (k. ú. Kral'ovany) Lokalita sa nachádza v masíve Žobráka (900 $1250 \mathrm{~m}$ ). Vek porastov je približne 190 rokov (buk $80 \%$, jedl'a $10 \%$, smrek $5 \%$ a $5 \%$ cenné listnáče, JV expozícia). V tejto oblasti ležia vedl'a seba NPR Šrámková a NPR Š́tovská dolina.

\section{Sučianska dolina - záver (k. ú. Sučany)}

Predpokladaná hniezdna lokalita je súčast'ou NPR Kl'ačianska Magura. Bukový les ochranného typu má asi 165 rokov (JV expozícia). Nadmorská výška hlasových záznamov oboch vokalizujúcich jedincov bola 950 - $1300 \mathrm{~m}$. Opakované húkanie jedinca bolo pozorované aj 11. 9. 2013 v širšom okolí lokality. 
Vel'ká Bránica (k. ú. Belá)

Hlasové prejavy pochádzali z dvoch miest. Najviac záznamov $(\mathrm{n}=5)$ pochádza od sedla Žitné v NPR Vel'ká Bránica (850 - 1050 m n. m.), kde je aj predpoklad hniezdnej lokality. Bukový porast asi 165 ročný je na južných svahoch. Jedno pozorovanie pochádza z opačnej strany doliny od Dlhého vrchu s porovnatel'nou nadmorskou výškou. Na lokalite bolo pozorovanie jednej sovy aj 15. 11. 2014 (Hrdý in verb.).

\section{Vyhnaná - Vel'ký Rozsutec (k. ú.}

Terchová)

Hlasové prejavy zaznamenaného páru pochádzali z väčšej oblasti tiahnucej od začiatku Kremennej doliny po Stohový potok v závere doliny Vyhnaná (1000 - 1200 m n. m., JZ expozícia). Celá oblast' je súčast'ou NPR Rozsutec, vek porastov je 175 rokov ( $85 \%$ buk, $10 \%$ smrek, $5 \%$ jedl'a).

\section{Medziholie (k. ú. Zázrivá)}

Zaznamenaný pár bol najčastejšie počutý na V časti lokality. Pri tejto lokalite bolo podozrenie na hniezdny pár z predošlej lokality, ale oba páry boli opakovane paralelne hlasovo zdokumentované. Bukový les ochranného typu má asi 165 rokov, SV expozíciu $(1000-1200$ m n. m). Dňa 15. 8. 2015 bol na lokalite nájdený čerstvo uhynutý jedinec sovy dlhochvostej (pravdepodobne mladý). Počas jari 2016 na základe zvukových záznamov na tejto lokalite bol zaznamenaný húkajúci pár.

\section{Horný Černík (k. ú. Turany)}

Lokalita sa nachádza v J predhorí Malej Fatry v tesnej blízkosti hranice NP v lesoch hospodárskeho typu. Nadmorská výška J exponovaných porastov sa podl'a hlasových prejavov pohybovala od 650 do $800 \mathrm{~m}$, vek porastu približne 120 rokov, porast tvoril výlučne buk. Okolité porasty tvoria rôzne staré porasty, širšie okolie plochy sa vyznačuje silnou fragmentáciou lesa lesohospodárskou činnost'ou. Lokalita sa nachádza v tesnej blízkosti rozsiahlych kosných lúk.
Kozinec (k. ú. Lipovec)

Opakované hlasové prejavy páru boli z oblasti masívu Nad Kýčerou (900 - 1050 m n. m.). Lokalita bola sledovaná aj v rokoch 2014 2015, až na jar 2016 bol zaznamenaný teritoriálny hlas sovy. Vek takmer výlučne bukového hospodárskeho lesa je približne 140 rokov, ide o JV expozíciu. Územie je výrazne fragmentované postupujúcou lesohospodárskou činnost'ou.

\section{Čiert'až (k. ú. Turčianske Kl'ača-} ny)

Pár bol opakovane zaznamenaný vo výškach 1000 - 1150 m n. m. Odhadovaný vek JV exponovaných porastov hospodárskeho typu je približne 120 rokov (buk $65 \%$, smrek $30 \%$, $5 \%$ cenné listnáče ).

Plešel (k. ú. Nezbudská Lúčka) Opakované hlasové prejavy oboch jedincov boli zaznamenané v $\mathrm{Z}$ orientovaných porastoch masívu Plešela (800 - $900 \mathrm{~m}$ n. m.). Vek porastu je približne 135 rokov (buk $50 \%$, dub $10 \%$, smrek $20 \%$, cenné listnáče $20 \%$ ). Oblast' je vystavená nadmernému ruchu z cestnej komunikácie a železničnej trate z Domašínskeho meandra (Strečno). Územie je súčast'ou NPR Krivé a NPR Starý hrad.

\section{Malý Rozsutec (k. ú. Zázrivá)} Hlasové prejavy jedincov pochádzali z porastu nad Osadou pod Malým Rozsutcom v S svahoch Rovnej Hory (1000 m n. m.). Vek porastu je približne 140 rokov (jedl'a $40 \%$, smrek $40 \%$, buk $20 \%$ ). Územie je súčast'ou NPR Rozsutec so SZ expozíciou. Zaujímavost'ou je, že lokalita bola sledovaná v celom sledovanom období (2013 - 2016), ale až na jar 2016 sa potvrdil teritoriálny hlas páru na lokalite.

Ďalšie vlastné staršie pozorovania pochádzajú už z viacerých lokalít: Párnica - Kačov (3. 10. 2004, 28. 2. 2008, 2. 4. 2010, 15. 3. 2011), Vel'ká Lučivná (28. 3. 2007, 29. 2. 2008, 26. 3. 2010) NPR Šrámková (22. 10. 2006, 17. 3. 2012), NPR Šíp (25. 10. 2004). 


\section{Diskusia}

Hustota hniezdnych párov na Slovensku môže byt' miestami až 8,7 páru/100 $\mathrm{km}^{2}$ (Krištín 1991), pričom môže byt' lokálne početnejšia ako sova lesná. Z oblasti Oravíc s prevahou ihličnatých lesov je odhadnutá hustota až 10,7 páru $/ 100$ km$^{2}$ (Hol'ma \& Michalec in Karaska et al. 2014). Hordowski (1999) uvádza z pol'ských Bieszczad a Sanocko-Turczańskych hôr hustotu 0,25 - 0,27 páru/10 $\mathrm{km}^{2}, \mathrm{v}$ národnom parku Roztocze Stachyra et al. (2005) zistil 0,6 - 1,0 páru/10 km². Na Šumave zistil Kloubec et al. (2005) 0,02 - 0,04 páru/10 km², Vermouzek et al. 2004 v Beskydoch podobne 0,2 páru/10 $\mathrm{km}^{2}$. Tishechkin \& Ivanovsky (1998) v oblasti Rosson v Bielorusku 0,7 - 0,9 páru/10 km². Avontis et al. (1999) na ôsmich výskumných plochách v Lotyšsku zistil hustotu 0,5 páru/10 $\mathrm{km}^{2}$. Hustota hniezdnych párov môže byt' umelo zvyšovaná inštalovaním vhodných búdok, ktoré druh ochotne prijíma (Karaska 2007).

$\mathrm{V}$ nehniezdnych rokoch je druh vel'mi nenápadný a pomerne t’ažko zistitel'ný (Korňan 2008). Na základe viacročných skúseností z Oravy sa predpokladá, že adultné vtáky ostávajú verné svojmu teritóriu (Karaska in Korňan 2008). Subadultné jedince sa podl'a neho najskôr potulujú a potom obsadzujú nové teritória.

Sova dlhochvostá bola zistená v území najmä v lesných porastoch, ktoré najmä svojou štruktúrou, vekom predurčovali jej výskyt. V území NP Malá Fatra bolo zistených 18 teritórií sovy dlhochvostej (obr. 1), pričom druh využíva najmä porasty vo veku od 120 do 190 rokov (obr. 2a), v nadmorskej výške 800 - 1200 $\mathrm{m}$ (obr. 2b). V sledovanom území bolo zistených 18 hniezdnych teritórií sovy dlhochvostej (7,96 páru na $100 \mathrm{~km}^{2}$ ). Celkový odhad vel'kosti populácie pre NP Malá Fatra na základe filtra vhodných porastov v GIS a znalosti územia odhadujem na 20 hniezdnych párov, čo predstavuje 8,8 páru na $100 \mathrm{~km}^{2}$, resp. 1 teritórium na $11,3 \mathrm{~km}^{2}$. Bashta (2009) uvádza zo západnej Ukrajiny hustotu druhu na úrovni $1,7-2,0$ párov $/ 10 \mathrm{~km}^{2}$, pričom najvyššiu hustotu dosahovala v zmiešaných, resp. bukových lesoch v nadmorskej výške 1100 - 1300 m. Hustota druhu zistená v Škandinávii a Bielorusku bola
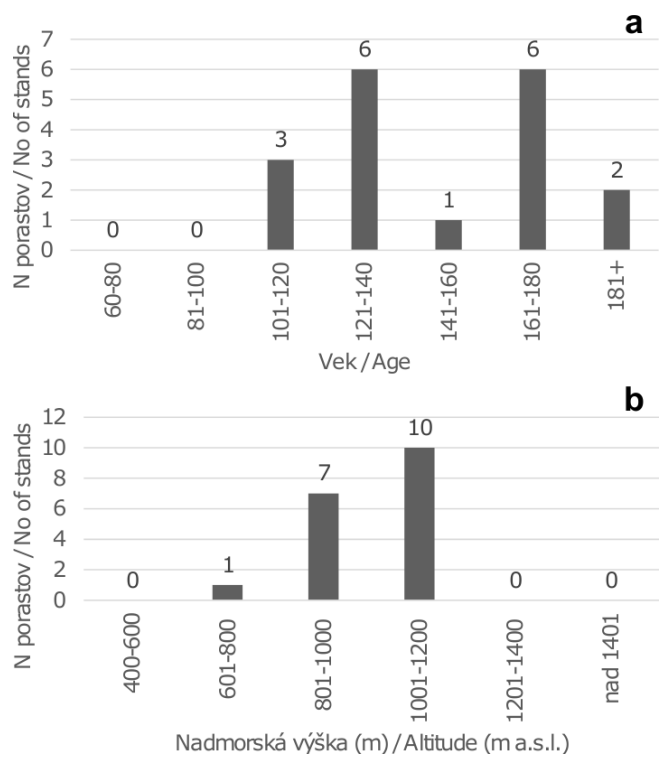

Obr. 2. Vek lesných porastov $v$ teritóriách sovy dlhochvostej (a); nadmorská výška hniezdnych teritórií sovy dlhochvostej v NP Malá Fatra $(\mathrm{b} ; \mathrm{n}=18)$.

Fig. 2. Age of forest stands in the Ural owl territories (a); altitude of breeding territories of the Ural owl in the Malá Fatra National Park ( $b ; n=18)$.

0,5 - 1,0 hniezdiacich párov/10 $\mathrm{km}^{2}$ (Lundberg 1981, Pietiäinen 1989, Tishechkin \& Ivanovsky 1998), v juhozápadnom Pol'sku až 4,5 - 5,0 párov/10 km² (Cwikowski 1995).

Až 61,5\% lesných porastov na území NP Malá Fatra je vo veku do 80 rokov a nie sú pre hniezdenie sov vhodné. Celkom $83 \%$ predpokladaných hniezdnych lokalít bolo zistených v porastoch nad 120 rokov. Jednotlivé porasty mali od 79 do $100 \%$ prirodzeného drevinového zloženia. Druh bol zistený v porastoch s prevažne južnou expozíciou (13 teritórií, 73 \%). Preferencia južnej expozície môže súvisiet' so skorším vytopením svahov v skorých jarných mesiacoch a tým aj s lepšou dostupnost'ou koristi. Tieto svahy poskytujú v zimných mesiacoch pri slnečnom počasí aj väčší tepelný komfort pre druh. Podobne zistili Bolboaca et al. (2018) v Rumunsku, kde sova dlhochvostá vykazovala vysokú asociáciu s lesmi so stromami staršími ako 80 rokov, zatial' čo mladé lesy a podrast boli využívané ovel'a menej. Tento druh tiež vykazoval tendenciu vyhnút' sa rúbaniam a strmím svahom. Výskyt druhu pri vyšších nadmorských výškach je ovplyvnený aj 


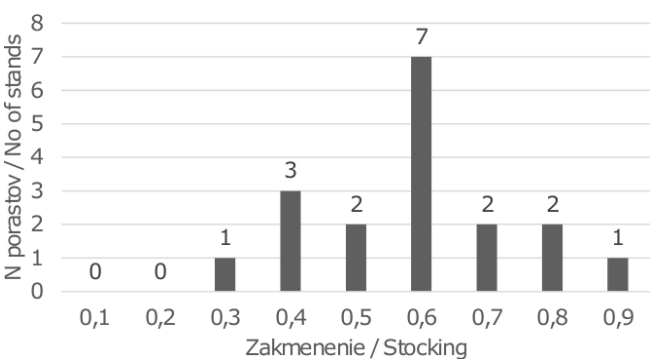

Obr. 3. Zakmenenie lesných porastov s výskytom sovy dlhochvostej $(n=18)$.

Fig. 3. Stocking of forest stands with an occurrence of the Ural owl $(n=18)$.

výraznou aktivitou človeka v predhorí (Vrezec \& Tome 2004). Výskum z Estónska ukazuje, že v obhospodarovaných lesoch nedostatok vhodných možností na hniezdenie môže obmedzit' počet druhu (Lohmus 2003).

Výskum prevádzaný v Pol'sku potvrdil hniezdenie druhu v lesoch nad 100 ha plochy a s vekom nad 60 rokov, avšak samotné porasty boli obklopené rozsiahlejšími lesmi bez otvorených plôch (Bylicka et al. 2010).

Až $10(55,5 \%)$ zistených predpokladaných hniezdnych lokalít sa nachádza $\mathrm{v}$ rámci národných prírodných rezervácií s najvyšším 5 . stupňom ochrany, 4 (22,2\%) predpokladané teritóriá boli v ochranných lesoch a tiež $4(22,2 \%)$ lesné porasty boli súčast'ou hospodárskeho lesa. Dva lesné porasty sa nachádzali v priamom susedstve s rezerváciou. Prvé dve kategórie lesných porastov môžeme považovat' za prioritné čo sa týka výskytu druhu v chránenom území. Podobne o preferencii lesov sovami v rezerváciách pred hospodárskymi lesmi zistil Lohmus (2003), pričom v rezervácii dosahovala hustotu 2,7 páru/10 km², v lesoch s manažmentom len 1,13 páru/10 km², je teda zjavné, že v obhospodarovaných lesoch nedostatok vhodných možností na hniezdenie môže obmedzit' početnost' druhu.

Hlavným dôvodom je dostupnost' vhodných vel'kých dutín či polodutín v stromoch, ktoré sova využíva na hniezdenie, ale aj pokoj vd'aka nečinnosti človeka. Sova dlhochvostá bola najčastejšie zistená $\mathrm{v}$ porastoch so zakmenením menším ako 0,6 (celkom 13 teritórií, 72,2%), len $5(27,7 \%)$ teritórií sa nachádzalo v poras- toch s vyšším zakmenením (obr. 3). Tento fakt odzrkadl'uje nielen samotnú vel'kost' sovy ale aj možnost' lovit' korist' v interiéri lesa.

Do konca roka 2018 boli vyt'ažené lesné porasty v $2(11,1 \%)$ hniezdnych teritóriách sovy dlhochvostej. Typický príklad masívneho odlesnenia vidiet' na území Vrátnej doliny, kde boli vyt'ažené viaceré vhodné porasty. Podobne bola v území vyt’ažená Kúrska dolina. Na základe porovnania výsledkov z ostatného územia v Malej Fatre sa môžeme domnievat', že vo Vrátnej doline aj v Kúrskej doline by bolo možné za optimálnych podmienok hustejšie obsadenie sovou ako je to za súčasných podmienok. Vo Vrátnej doline bola potvrdená sova dlhochvostá len z oblasti NPR Rozsutec v jej východnej časti. V minulosti známy údaj o výskyte druhu v časti NPR Chleb nad symbolickým cintorínom nebol potvrdený počas trvania monitoringu (Kalaš in verb.).

\section{Záver}

Podl'a výsledkov tohto monitoringu je potrebné zabezpečit' čo najväčšiu rozlohu porastov nad 120 rokov, príp. lesné porasty s vhodným lesohospodárskym manažmentom, kde je dostatok zlomov starších stromov, pahýl'ov, či vyhnitých dutín. Vhodnejším lesohospodárskym spôsobom je aj tzv. výberkový spôsob hospodárenia a prírode blízke hospodárenie $\mathrm{v}$ lesoch pred holorubným spôsobom s odstránením celého porastu. Podrastový hospodársky spôsob s vytváraním rúbanísk vytvára výrazný rušivý prvok v lesnom prostredí a je najviac kritizovaný práve na území národných parkov (Saniga \& Bruchánik 2009). Je optimálne, aby na lokalitách (aj v hospodárskych lesoch pri výberkovom spôsobe hospodárenia) ostávali aj stromy ponechané na dožitie.

Oblasti s vyšším výskytom tohto druhu by bolo vhodné prehodnotit' vhodné lesné porasty po stránke vekovej a druhovej a tieto účinnejšie chránit' formou A zóny národného parku. $\mathrm{V}$ ochranných lesoch s možným čiastočným hospodárením by bolo potrebné v týchto lesoch v súčinnosti s lesníkmi zachovat' požadované možnosti pre výskyt a hniezdenie druhu. 
Z pohl'adu disturbancii biotopov je nutné úplne zamedzit' výstavbe nových lesných ciest. Takto sprístupnené územia trpia nielen samotnou zmenou štruktúr lesných celkov, ale lokality sú zo strany človeka aj viac navštevované, čo pre hniezdiace sovy môže predstavovat' významný rušivý vplyv.

\section{Pod'akovanie}

Za pomoc pri spracovaní údajov d'akujem Petrovi Urbanovi, Michalovi a Márii Balážovcom.

\section{Literatúra}

Avotins A., Graubics G., Kemlers A., Kreslins V., Kuze J. \& Lolans U. 1999: Numbers and breeding densities of owls in Latvia. - Vogelwelt 120: 333-337.

Baláž M., Repel M. \& Slobodník R. 2018: Unusual frequent occurrence of Ural owls (Strix uralensis) in urban and rural habitats in the lowlands of southern Slovakia during the winter 2017/2018. - Slovak Raptor Journal 12: 63-69.

BALla M. 2010: Ural owl (Strix uralensis) nesting in floodplain forest in the Východoslovenská rovina Plain. - Slovak Raptor Journal 4: 105-108.

Bashta A. T. 2009: Ural Owl Strix uralensis population dynamics and range expansion in western Ukraine. In: Johnson D. H., Van Nieuwenhuyse D. \& Duncan J. R. (eds) Proc. Fourth World Owl Conf. Oct-Nov 2007, Groningen, The Netherlands. - Ardea 97: 483-487.

BOLBOACA L.E., IORDACHE I. \& ION C. 2018: Factors related with the distribution of Ural owl Strix uralensis macroura in Eastern Romania, 2018. — North-Western Journal of Zoology 14: 193-198.

Brambilla M., Bassi E., Ceci CH. \& Rubolini D. 2010: Environmental factors affecting patterns of distribution and co-occurrence of two competing raptor species. - Ibis 152: 310-332.

BufKa L. \& KLOUBeC B. 1999: The history and current status of the Ural Owl (Strix uralensis) in Bohemian Forest (SW Czech Republic). - Buteo: 42-43.

Bylicka M., KaJtoch L. \& Figarski T. 2010: Habitat and landscape characteristics affecting the occurrence of Ural Owls Strix uralensis in an agroforestry mosaic. - Acta Ornithologica 45: 33-42.

Cwikowski C. 1995: Ptaki doliny potoku Stebnik i terenow sasiednich (Park Krajobrazowy Gor Slonnych).
- Badania nad ornitofauna Ziemi Przemyskiej 3: $57-70$.

Černecký J., Darolová A., Fulín M., Chavko J., KaRASKA D., KRIŠTín A. \& RidZOŇ J. 2014: Conservation status of birds in 2008 - 2012 in Slovakia.-State nature conservancy of the Slovak republic, Banská Bystrica.

DANKo Š. 1994: Správa o činnosti Skupiny pre výskum a ochranu dravcov a sov v ČSFR za rok 1992. — Buteo 6: 121-151.

DANKo Š., KARASKa D. \& KRIŠTín T. 2002: Sova dlhochvostá (Strix uralensis). - Pp. 371-373. In: DANKO Š., Darolová A. \& Krištín A. (eds). Rozšírenie vtákov na Slovensku. Veda, Bratislava.

DraveckÝ M. \& OBUCh J. 2009: Contribution to the knowledge on the synanthropization and dietary specialization of the Ural Owl (Strix uralensis) in urban environment of Košice city (East Slovakia). — Slovak Raptor Journal 3: 51-60.

ENGLEDER T. 2003: Re-introduction of the Ural Owl (Strix uralensis) on the Austrian side of the Bohemian Forest in 2001. — Buteo 13: 97-99.

Hordowski J. 1999: Ptaki polskich Karpat Wschodnich i Podkarpacia. - Oficyna Wydawnicza Mercator, Przemyśl.

Chylarecki P., Sikora A. \& Cenian Z. 2009: Monitoring ptaków legowych. Poradnik metodyczny dotyczàcy gatunków chronionych Dyrektywà Ptasià. - GIOŠ, Warszawa.

KARASKA D. 2007: Large numbers of young in nests of Tawny Owls (Strix aluco). — Slovak Raptor Journal 1: $53-56$.

Karaska D., Cichocki W. \& Kocian L'. 2014: Hniezdne rozšírenie vtáctva Oravy. - SOS/BirdLife Slovensko, Bratislava,

Karaska D., Michalec R. \& Holma J. 1997: Hniezdenie sovy dlhochvostej (Strix uralensis) na Orave. — Buteo 9: 85-92.

KLOUBEC B. 1997: Dosavadní výsledky projektu reintrodukce puštíka bělavého (Strix uralensis) v Národním parku Šumava. - Buteo, 9: 115-122.

Kloubec B., Bufka L. \& Obuch J. 2005: Puštik belavý (Strix uralensis) na Šumave: nárůst populace, d'alší prokázaná hnízdení a poznatky o skladbe potravy. — Buteo 14: 69-75.

KorŇAn M. 2008: Prvé dokázané hniezdenie sovy dlhochvostej (Strix uralensis) v Krivánskej Fatre (S Slovensko). — Tichodroma 20: 140-142. 
KORPIMÄKI E. 1988: Effects of Territory Quality on Occupancy, Breeding Performance and Breeding Dispersal in Tengmalm's Owl. - Journal of Animal Ecology 57: 97-108.

KRIŠTíN A. 1991: Vtáčie spoločenstvá charakteristických biotopov Pol'any. - Stredné Slovensko 10: 165-182.

Krištín A., Mihók J., Danko Š., Karaska D., PaČEnovSKÝ S., Saniga M., BoĎová M., Balázs C., Šotnár K., KorŇAn J. \& OlekšÁK M. 2007: Distribution, abundance and conservation of the Ural Owl Strix uralensis in Slovakia. - Pp, 8-15. In: MüLler J, Scherzinger W. \& Moning C. (eds): European Ural Owl workshop. Tagungsbericht Heft 8. - National Park Bayerischer Wald, Grafenau.

Lengyel J. 2004: Výskyty sovy dlhochvostej (Strix uralensis) na Podunajskej nížine (juhozápadné Slovensko) v zime 2002-2003. - Tichodroma 16: 71-74.

Lohmus A. 2003: Do Ural owls (Strix uralensis) suffer from the lack of nest sites in managed forests? Biological Conservation 110: 1-9.

Lundberg A. 1981: Population ecology of the Ural Owl Strix uralensis in Central Sweden. - Ornis Scandinavica 12: 111-119.

Morosinotto CH., Thomsonand R. \& KorpimäKi E. 2010: Habitat selection as an antipredator behaviour in a multi-predator landscape: all enemies are not equal. - Journal of Animal Ecology 79: 327-333.

Ortego J. 2007: Consequences of Eagle Owl nest-site habitat preference for breeding performance and territory stability. — Ornis Fennica 84: 78-90.

PAČEnOVSKÝ S. \& SHurulinkov P. 2008: Latest data on distribution of the Pygmy Owl (Glaucidium passerinum) in Bulgaria and Slovakia including population density comparison. - Slovak Raptor Journal 2: 91-106.

PietiäInen H. 1989: Seasonal and individual variation in the production of offspring in the Ural owls Strix uralensis. — Journal of Animal Ecology 58: 905-920.
SAniga M. \& BRUChÁNIK R. 2009: Prírode blízke obhospodarovanie lesa. - Národné lesnícke centrum, Zvolen.

Shurulinkov P., Stoyanov G., Komitov E., Daskalova G. \& Ralev A. 2012: Contribution to the Knowledge on Distribution, Number and Habitat Preferences of Rare and Endangered Birds in Western Rhodopes Mts, Southern Bulgaria. Strigiformes and Piciformes. Acta Zoologica Bulgarica 64: 43-51.

SCHÄFFER N. 1993: Der Habichtskauz (Strix uralensis) in Ostbayern - ein Kulturfolger? - Jahresber. OAG Ostbayern 20: 21-38.

Stachyra P., Tchorzewski M., Kobylas T., Cymbala R., Mazurek P. \& Frączek T. 2005: Rozmieszczenie, liczebność oraz preferencje siedliskowe puszczyka uralskiego Strix uralensis i włochatki Aegolius funereus w lasach Roztocza i Puszczy Solskiej. - Notaki ornitologiczne 46: 41-50.

Strøm H. \& Sonerud G. 2001: Home range and habitat selection in the Pygmy Owl Glaucidium passerinum. — Ornis Fennica 78 145-158.

ŠOP 2015: Program starostlivosti o Chránené vtáčie územie Malá Fatra 2016 - 2045. — Štátna ochrana prírody SR, Banská Bystrica.

TishechKin A.K. \& Ivanovsky V.V. 1998: Ural Owl Strix uralensis in north of Byelarus: nesting density and breeding biology. - Berkut 7: 55-63.

Vermouzek Z., KřeneK D. \& Czerneková B. 2004: Increase in numbers of Ural Owls (Strix uralensis) in the Beskydy Mts. (NE Czech Republic). — Sylvia 40: 151-155.

VReZeC A. \& Tome D. 2004: Altitudal segregation between Ural Owl Strix uralensis and Tawny Owl S. aluco: evidence for competitive exclusion in raptorial birds. — Bird Study 51: 264-269.

Wójcik J. D., Skórka P. \& Martyka R. 2000: Wystepowanie puszczyka uralskiego Strix uralensis w Lasach Ralowsko-Wierzchoslawickich kolo Tarnowa. — Notatki Ornitologiczne 41: 248-250. 